\title{
Selected Reference Books of 1987-88
}

\author{
Eileen McIlvaine
}

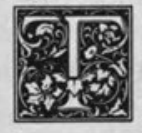

his article follows the pattern set by the semiannual series initiated by the late Constance $\mathrm{M}$. Winchell more than thirty years ago and continued by Eugene P. Sheehy. Since the purpose of the list is to present a selection of recent scholarly and general works of interest to reference workers in university libraries, it does not pretend to be either well balanced or comprehensive. A brief roundup of new editions of standard works is provided at the end of the article. Code numbers (such as AD540, CJ331) have been used to refer to titles in Guide to Reference Books. (10th ed., Chicago: American Library Assn., 1986).

\section{PERIODICAL INDEXES}

H. W. Wilson Company. Wilsondisc. New York: H. W. Wilson, 1987- . One disc for each database, cumulated and updated quarterly. Price varies.

The Wilson indexes are familiar faces in the reference collection. The H. W. Wilson Company has built a reputation on its indexing, and the quality is unquestioned. Available online for some time, these same databases are now available in a different format, CD-ROM, which offers several unique advantages over the other versions. These compact discs and their search software are meant for a relatively unsophisticated user to search a large database in a relatively sophisticated man- ner, without requiring knowledge of specialized commands.

The system runs on an IBM XT or compatible, with $640 \mathrm{~K}$ of memory and DOS 3.1 , and can support several makes of CD players. The discs include three or more years worth of citations, depending on the database, and are updated quarterly. Besides the Wilson indexes, the GPO Monthly Catalog, Film Literature Index (annual updates only for these two), and the MLA Bibliography are available.

The user chooses from four different search modes-Browse, Wilsearch, Wilsonline, and Expert Wilsonline. The Browse mode is similar to using the printed index. One types in the subject heading, and the screen displays an alphabetic thesaurus of neighboring terms and cross-references, and the number of citations associated with each term. The Wilsonline and Expert Wilsonline, as their names imply, both require knowledge of the Wilson command language. Since these two modes are so similar, it seems unnecessary to have them both.

Wilsearch, however, is the real success of the system, for it allows sophisticated search strategies, truncation, and Boolean operations, without having to know much about commands. In this mode, terms are searched as keywords in both subject or title fields, and these terms can be combined. Users can also search by author or subject heading or by journal name. This

Eileen Mcllvaine is Head of Reference, Butler Library, Columbia University, New York, New York 10027. Although it appears under a byline, this list is a project of the reference departments of Columbia University Libraries, and notes are signed with the initials of these individual staff members: Mary Cargill, Beth Juhl, Anita Lowry, Kirk Moll, Louise Sherby, Sarah Spurgin, Junko Stuveras, Perry Willett (Butler Library); Jerry Breeze and William Middleton (Lehman Library). 
search option lets users of all levels of understanding perform efficient, thorough searches simply and quickly-exactly what a database on CD-ROM should do.

Some minor complaints are too many beginning menus and failure to display the name of the index on the screen at all times, so that someone walking up to the workstation may not know what the colorful display is all about.

Two features that merit praise are the printing and online functions. Printing a citation is easy, unlike some other CDROM products. One need only press one key to print the currently displayed citation or all citations found in the search.

The online feature allows users to update searches past the date of the compact disc (provided that a modem is attached). Subscribers are billed only for telecommunications charges, not for connect time or citation royalties. In any of the search modes, the user simply presses a key, and the system will dial up the Wilson mainframe computer, perform the search, transfer those entries (if any) that have been input since the cutoff date of the disc, and then disconnect. This means that searches can be performed first on the disc, and then updated online inexpensively-the equivalent of searching the entire database online.

The Wilsondisc system allows users to perform their own searches with no sense of urgency or intimidation. It is highly recommended that any library serving either undergraduate or graduate students consider subscription to at least one of the Wilson indexes on CD-ROM.-P.W.

\section{THE PRESS}

Hoeder, Dirk, and Christiane Harzig. The Immigrant Labor Press in North America 1840s-1970s: An Annotated Bibliography. Bibliographies and Indexes in American History, 4- . New York: Greenwood, [1987]- . (ISBN 0-313-246386). LC 87-168. V.1, Migrants from Northern Europe (278p., \$65); V.2, Labor Migrants from Eastern and Southeastern Europe (in press); V.3, Migrants from
Southern and Western Europe (in press).

This annotated bibliography is an outcome of the Labor Newspaper Preservation Project (LNPP) launched in 1978 by scholars from eleven European and North American countries. The full name of the project explains its purpose: Bibliography and Archival Preservation of Non-English Language Labor and Radical Newspapers and Periodicals in North America, 1840s1970 s. The project initially planned to include South American, Asian, and African immigrants, but the lack of financial support has limited the present enterprise to the presses of immigrants from West and Eastern Europe in the U.S. and Canada. Institutions in North American and European countries have been funding the microfilming project of the respective language groups.

The volume in hand and the first in the series, Migrants from Northern Europe, includes labor presses of the Danes, Swedes, Norwegians, Finns, Icelanders, and the Scandinavians in general. Each language group is covered by an annotated bibliography and an essay on the history of immigration and immigrant presses of that group.

An entry contains: title, variant titles, if any, translations of the title into English, publication dates, frequency, category of the publication, type of preservation copy, depositories, and a note briefly describing the paper as to sponsoring body, history, etc.

RLIN and OCLC locations are also noted. Each section has indexes by title and place and a chronological table. There is a combined title index at the end. This bibliography is very useful as a survey of immigrant presses, a union catalog and an historical study of these periodicals-J.S.

\section{NAMES}

A Lexicon of Greek Personal Names. Ed. by P. M. Fraser and E. Matthews. Oxford: Oxford Univ. Pr., 1987- . V.1, The Aegean Islands, Cyprus, Cyrenaica. 489p. $\$ 90$ (ISBN 0-19-86422-9). LC 87-12344.

Begun by a committee from the British Academy in 1973, this Lexicon is intended 
to revise, update, and expand the work of Wilhelm Pape in his Wörterbuch der Griechischen Eigenammen (volume 3 of Handwörterbuch der Griechischen Sprache, 1842-43). The new Lexicon demonstrates once again the ability of twentieth-century computing to fulfill the aspirations of monumental nineteenth-century works.

Names from thousands of inscriptions and printed sources are gathered here in one alphabet, with the source, geographic location, any identifying information (e.g., "daughter of"), and dates that are known or surmised from other evidence. Time coverage extends from the earliest known Greek inscriptions up to the Byzantine era. Excluded are all geographic names and mythological or epic names (though some fictitious names are included, as well as mythological characters, such as founders of cities, whose names are repeated often among the local populace). Also excluded are Greek names in non-Greek script, though foreign names, such as those of Persian notables, do appear if transliterated into Greek script. Forthcoming volumes will cover, in turn, Attica, the Peloponnese and the Greek mainland, Macedonia and the Balkans, and coastal Asia Minor; an index volume will include all names with no geographic location, as well as bibliographies and analytical tables.

The Lexicon will prove extremely useful to epigraphers, papyrologists, and linguists; historians and students of classical literature will also find it helpful for specific references. One hopes that the editors and Oxford University Press have plans to make the data and database themselves available to scholars at some point in the future. Such a database, equipped with sophisticated search software, and combined with the Thesaurus Linguae Graecae database, would provide nearcomplete online access to the written word in Greek.-B.J.

\section{RELIGION}

Antisemitism: An Annotated Bibliography. The Vidal Sassoon International Center for the Study of Antisemitism, the He- brew University of Jerusalem; ed. by Susan Sarah Cohen. Garland Reference Library of Social Science, v.366-

New York: Garland, 1987- . LC 87-

11842. V.1, 1984-1985. 392p. \$47 (ISBN 0-8240-8532-9).

This excellent bibliography is the first volume in a new bienniel bibliographic series on the topic of anti-Semitism, begun by the Center for the Study of Antisemitism (established 1983). It covers secondary literature including "books, dissertations, masters' theses, and articles from periodicals and collectionspublished in 1984-1985. It does not include newspaper articles, reviews, and works of fiction." In this work "antisemitism is defined as antagonism toward Jews and Judaism as expressed in writings. . .in the visual arts. . . and in actions" (introd.). Related topics such as Christian-Jewish relations are included only when the author relates the subject to antisemitism. Parameters for inclusion are carefully defined for four large areas of material: the Holocaust period, Soviet Jewry, anti-Zionism, and the Arab-Israeli conflict, i.e., "works. . .which deal with antisemitism in the Arab world, but not with the political conflict between the State of Israel and its Arab neighbors" (introd.). Personal accounts of Jewish experience during the Holocaust and in the Soviet Union specifically discussing government policies of anti-Semitism are excluded.

The main section of the bibliography includes 1,255 annotated entries of materials in English, other European languages, Hebrew, and Yiddish. English translations are provided in brackets for works in languages other than French, German, Italian, and Spanish. The annotations are clear, concise, and a model of descriptive objectivity, summarizing the contents and point of view of the works being described. The bibliography is arranged under broad chronological headings and is subdivided for the modern period by region and country as appropriate. It also includes a section on bibliographies and reference works. Though the entries are arranged alphabetically under these fairly general headings, no section is so large 
that the contents cannot be quickly scanned (Germany, 1919-45, is the largest with 128 entries). Good subject access is also provided by a thorough subject index. The bibliography features two appendixes: a list of anti-Semitic periodicals (with publishers names and addresses) and a checklist of bibliographies published on anti-semitism and the Holocaust before 1984 including a list of "ongoing" bibliographies in the field of Judaica which regularly list material on antisemitism and the Holocaust"' (p.339). The volume ends with an author index and a list of periodicals and collections cited in the bibliography-K.M.

Charlesworth, James H. The New Testament Apocrypha and Pseudepigrapha: A Guide to Publications, with Excursuses on Apocalypses. ATLA Bibliography Series, no.17. Metuchen, N.J.: Scarecrow, 1987. 450p. \$42.50 (ISBN 0-8108-1845-0). LC 85-18350.

This is an indispensible bibliography for anyone doing research on the Christian literature of the first few centuries of the Common Era. It contains just over 5,000 citations to the primary and secondary literature concerning the extracanonical writings which "purport to be apostolic and scriptually [sic] equal to the $27 \mathrm{New}$ Testament documents"' (introd.). It forms a companion volume to Charleworth's earlier work, The Pseudepigrapha and Modern Research with a Supplement (Chico, Calif.: Scholars, [1981]), which covers writings relating to the Hebrew Scriptures. Excluded from the coverage of the present volume are: (1) The Apostolic Fathers (1 Clement, 2 Clement, Ignatius, etc.); (2) The Nag Hammadi Codices (except the Gospel of Thomas which is included, although not mentioned as an exception); (3) The Old Testament Pseudepigrapha; (4) Some early Syriac writings; (5) Earliest versions/translations of the New Testament, (6) Fakes; (7) Possible candidates (listed in the introduction).

The bibliography proper begins with five broad sections: general studies ( $562 \mathrm{ci}$ tations); apocalyptic literature (77); apocryphal acts (84); canon (168); and agrapha, fragments of unknown works (284). It then lists citations under the names of 99 major writings or cycles of writings. Entries are arranged alphabetically, giving basic information (with place of publication only, not publisher) and occasional brief annotations. When the work contains the original or translation of a text, it usually is noted in square brackets. Citations to the standard collections of translations are an exception to this policy; that the item contains a translation is not noted, but reference is given by the abbreviation of the collection in question. Materials in virtually all appropriate languages are included. The titles of books and periodical articles written in East European, East Asian, or Middle-Eastern languages (including all non-roman alphabets) are translated into English without transliteration. Fortunately, the titles of periodicals containing citations in these languages are transliterated. The coverage of the bibliography extends into the early 1980 s.

This work also has three introductory chapters that give a report of research on the New Testament Apocrypha and Pseudepigrapha and a helpful overview of the issues and texts relating to Christian and Jewish Apocalyptic literature. It also includes an author index.-K.M.

\section{Musto, Ronald G. The Peace Tradition in the} Catholic Church: An Annotated Bibliography. Garland Reference Library of Social Science, v.339. New York: Garland, 1987. 590p. \$67 (ISBN 0-8240-8584-1). LC 86-31950.

This annotated bibliography is the second volume in the author's "three-part study that hopes to document the history of the peace tradition in the Roman Catholic church from the Gospels to the twentieth century" (pref.). The first part is Musto's The Catholic Peace Tradition (Orbis, 1986), which is a narrative history, and the third part is projected to be an anthology of texts. It should be kept in mind when using this work that the author's stated purpose "is to show that there truly is a continuing, unbroken, and selfsustaining stream within catholicism that bridges the gap between the martyrs and pacifists of the early church and the work of John XXIII and the peacemakers of our 
own time" (pref.). In general, this does not detract from the descriptive character of the bibliography's annotations, although occasionally the author's point of view makes them more evaluative in nature.

The work has some 1,485 entries, nearly all of which have annotations ranging in length from a few sentences to several paragraphs. The entries are for materials in English, French, German, Italian, Spanish, Portuguese, and Latin and include items published through November 1986. Despite the wide variety of languages represented, this work is largely oriented to the student and general reader. Citations to articles in the standard Catholic encyclopedias are given throughout. In each section, many general works for background and introductory reading are included, which may or may not have special sections on peacemaking. Unfortunately specific bibliographic reference is not often given to the most relevant sections of these general works.

The bibliography has a classified arrangement, which begins with general works and continues chronologically, covering each period from ancient times to the present. Within sections it is subdivided quite finely and an average subdivision is only several pages long; so that although it lacks a subject index, access by subject is still quite easy to obtain. The greatest number of entries (945-1485) is in the final three chapters covering Europe since Vatican II, Latin America, and the United States. The entries include a wide variety of primary and secondary materials useful to anyone researching the Catholic peace tradition. The scope of these materials is also broad, covering materials that range from medieval writings on peace, to works about the just war tradition or pacifism, to theologies of peace, liberation, and social justice. The bibliography also has author, personal name, and title indexes.-K.M.

\section{FOLKLORE}

Ashliman, D. L. A Guide to Folktales in the English Language, Based on the AarneThompson Classification System. Bibli- graphies and Indexes in World Literature, no.11. New York: Greenwood, [1987]. 368p. \$45 (ISBN 0-313-25961-5). LC 87-15017.

The purpose of this guide is "to help readers find reliable texts of any given folktale [available in English], not only in its best-known version, but also in less familiar variants"' (introd.). The author, an associate professor of German at the University of Pittsburgh, has arranged the book by Aarne-Thompson numbers (Guide CF40, CF42), the standard folklore classification system. He provides brief plot summaries for the stories associated with each index number and then lists several collections in which versions of the story appear.

The author has also included a separate list of the titles of Grimm's tales, with their classification numbers. A brief bibliography of secondary works on the folktale, and a list of folktale collections is also included. The index lists the titles of betterknown stories and keywords from typical plots.

Though more selective than Norma Ireland's Index to Fairy Tales (Guide BD246) and its supplements, the plot summaries and arrangement make identifying stories and motifs easier, and this should prove useful in both general and specialized collections. - M.C.

Azzolino, David S. Tale Type- and MotifIndexes: An Annotated Bibliography. Garland Folklore Bibliographies, v.11; Garland Reference Library of the Humanities, v.565. New York: Garland, 1987. 105p. \$33(ISBN 0-8240-87887). LC 87-11866.

One of the results of the nineteenthcentury boom in folklore studies was the urge to classify, analyze, and compare folktales from different countries and cultures. Type and motif indexes, with which folklorists can arrange tales and elements in tales in numeric sequences, have been developed to make comparisons easier. The best-known system is the AarneThompson classification system, though other scholars have developed supplements and additions to Aarne-Thompson, or have devised their own. 
This bibliography is the first compilation of all published, including dissertations, tale type- and motif-indexes. The 186 entries are arranged alphabetically by author, and there are separate subject and geographic indexes. Libraries with strong collections in folklore should find this guide useful.-M.C.

\section{LITERATURE}

\section{Columbia Literary History of the United} States. Emory Elliot, gen. ed. New York: Columbia Univ. Pr., 1988. 1,263p. $\$ 59.95$ (ISBN 0-231-05812-8). LC 8714672.

As a somewhat abbreviated descendant of Spiller's Literary History of the United States [Guide BD411], the Columbia Literary History of the United States is very much the product of its time. Where Spiller presents a comprehensive and unified progress through the centuries, the new volume is "modestly post-modern: it acknowledges diversity, complexity, and contradiction" (pref.). While librarians will continue to treasure Spiller, they may appreciate the representation here of previously unchronicled groups, genres, and authors such as native Americans, experimental fiction, and Dashiell Hammett, and recent re-evaluations of the American canon.

The work is divided into five broad time periods, each with a different general editor. Each of these sections reflects very much the opinions and tastes of its editor; coverage is in no way uniform or complete. Thus, there are chapters on women writers in each of the three sections that cover the time period $1810-1945$, but none in the section from 1945 to the present. Chapters are by individual specialists and are signed. While there are many chapters on major American authors-Cooper, Dickinson, Poe, and so on, the majority deal with literary movements, ethnic, political, or social groups, and genres.

While the Columbia Literary History is furnished with an excellent index, it lacks the exhaustive bibliography of Spiller. Without a bibliography or footnotes, readers may have difficulty locating cited authors or works. Though by no means comprehensive, readers may find this work a compact and useful contemporary "take" on American letters-.BJ.

\section{THEATER}

Directory of Historic American Theatres. Ed. by John W. Frick and Carlton Wood. New York: Greenwood, [1987]. 374p. $\$ 45$ (ISBN 0-313-24868-0). LC 87-10709.

Sponsored by the League of Historic American Theatres, this directory attempts to list "all available vital data about theaters built in the United States" that are still in existence. The editors included "theatres which are still operating and virtually unchanged since they first opened, buildings for which only the shell remains, and theatres ... .where just the facade remains"' (pref.).

This list is based on work begun by the late Gene Chesley and supplemented by questionnaires sent to historical societies and libraries. It is arranged alphabetically by state, then by city The entries include information about structural features, including state dimensions and equipment, seating capacity and size of the auditoriums; the architect, if known, and the opening date. Though the titles of opening presentations, if known, are given, and a few of the major stars are listedwithout dates or titles of performancesthe emphasis is on the theaters as buildings, not on the performances presented in them.

There are two indexes: the first lists names, including any variations, of the theaters; the second index lists performers, architects, theater owners, and titles of any plays, operas, and films mentioned in the entries. Unfortunately, individuals are not identified by professions, so it is impossible, for example, to identify quickly the names of architects.

Wiliam C. Young's Famous American Playhouses, 1716-1899 (Guide BG92) provides much more extensive information for the theaters it covers, and documents theaters no longer in existence. But only 118 buildings are covered, in contrast to the nearly 900 listed in this directory. Libraries with major theater collections will need both works.

An added bonus is the photographs of 
nearly 80 theaters, ranging from Carnegie Hall to Gallie Hall in Tallahassee, Florida, whose use as a loading dock does not completely obscure its theatrical origins.M.C.

Evans, James E. Comedy: An Annotated Bibliography of Theory and Criticism. Metuchen, N.J.: Scarecrow, 1987. 397p. $\$ 37.50$ (ISBN 0-8108-1987-2). LC 874748.

Comedy has never received the serious critical attention that tragedy has. Beginning, it seems, with Aristotle, comedy has not gotten any respect. However, as this bibliography demonstrates, in this century a more serious study of comedy has begun.

Evans has selected and annotated about 3,000 works on comedy, ranging from the purely theoretical to the specific, from Aristophanes to the Marx Brothers, from the history of cartoons to the psychology of the joke. He has divided the citations into several sections. General works on comedy are separated into the periods in which they were written, mainly pre-and post-1900. (One notices immediately that few works on comedy were written before 1900.) Works on specific authors are grouped under their respective nationalities. Finally, works about related subjects like satire, farce, jokes, and so on are grouped under their respective headings.

Each entry is numbered, with author and personal subject indexes. The citations chosen are English language only, which explains the skimpy number of entries under the national literatures. The personal subject index is useful for finding all the entries mentioning a particular author, for there are works that examine several authors' works. However, there is no subject index as such, only a list of "see also" entry numbers at the end of each section. This is slightly annoying, for there is no way to tell from the number what the entry is specifically about, and there can be as many as 100 see also entries listed.

Still, this bibliography brings together a wide range of materials, making it a good source for those interested in researching comedy in its various forms and historical developments. - P.W.

Richel, Veronica C. The German Stage, 1767-1980. Bibliographies and Indexes in the Performing Arts, no.7. New York: Greenwood [1988]. 230p. $\$ 39.95$ (ISBN 0-313-24990-3). LC 87-25155.

The author, an associate professor of German at the University of Vermont, hopes this book will "facilitate investigation of the working repertory of German theatres between 1867 and 1890 by recording the productions of more than four thousand plays in ten selected [German, including Vienna] cities" (introd.).

She compiled the information from thirty-five published chronicles available in the United States; German records and printed sources not available in the United States were not used. Performances listed in volume 11 of the second edition of Goedeke's Grudriss zur Geschiechte der deutschen Dichtung (Guide BD811) were not included since this compilation is widely available.

The entries are listed alphabetically by playwright. Citations to biographical information located in ten standard sources are provided. The plays are then listed alphabetically under each author, with cryptic abbreviations indicating the genre; the number of acts; the language of the original play, if not German; a date of publication (not necessarily the first date of publication); and a year with the city or cities where the play was performed. The name of the theater and opening and closing dates are not provided, nor is the source of the information given. There is an index to play titles.

The lack of documentation and the unfortunate fact that German records were not examined means that this work will be most useful for its biographical references. This book, which appears to have been reproduced from a typed manuscript, is not up to Greenwood Press' usual production standards. - M.C.

\section{FILM}

Wulff, Hans Jurgen. Bibliographie der Filmbibliographien/Bibliography of Film Bibliog- 
raphies. München: K. G. Saur, 1987. 326p. \$50 (ISBN 3-598-10630-0).

Listing over 1,000 titles, this work is the most comprehensive guide to film bibliographies yet published and thus is a welcome addition to film reference collections. It casts a wide net to include bibliographies published as books, catalogs of individual library collections, pamphlets, articles, and parts of articles and books, in English and European languages. As a bibliography of bibliographies, it specifically excludes "filmographies" i.e., lists of films, although an exception has been made for filmographies of adaptations of literary works; an occasional filmography has slipped into other sections as well. Coverage appears to extend to materials published through 1985.

The bibliography is arranged according to a fairily detailed classification system that encompasses all aspects of film research and literature, including film theory, film and other disciplines, film techniques, film history, genres, national cinemas, persons and institutions, and related areas of mass media research. Liberal "see also" references at the end of each section alert the reader to related references in other sections; in addition, there are author and subject indexes, though the forms of entry used for corporate authors render them difficult to locate in the indexes. An unusual but useful feature is the list of "retrospective, cumulative indexes to individual film journals" (p. 64-70), a guide to cumulative indexes to such important journals as Cahiers $d u$ Cinema and Close Up.

The individual citations may appear strange to American eyes, partly because of the bibliographic format used and partly because of the fact that the bibliography is produced directly from typewritten copy. But the citations are complete, and many entries include annotations.A.L.

\section{SPORTS}

Dictionary of Sports Quotations. Ed. by Barry Liddle. London, New York: Routledge \& K. Paul, 1987. 210p. \$20
(ISBN 0-7102-0785-9). LC 86-21922.

The Dictionary of Sports Quotations attempts to "select quotations for their bearing on the human condition, for their profundity and for the way in which they provide a blanced insight into individual sports and related issues" (pref.). Done primarily from the British perspective, the volume tries to include quotations from the sports literature in all sports as well as quotations on related topics such as Fitness/Health, Journalism/Television, and Winning. The arrangement is by sport and then alphabetically by author. If more than one quote is chosen from a particular author, the quotes are arranged alphabetically according to the source of the quote and then by date.

The subject index is arranged by keyword and within each subject the entries are alphabetical by sport/topic. A similar arrangement is used in the author index. Because there are no cross-references (i.e., "Real Tennis see Lawn Tennis" or "Tennis see Lawn Tennis"), it is necessary to scan the complete "List of Sports and Topics" to find some entries (e.g., bowling is under "Bowls" and "Tenpin Bowling"). Recommended for comprehensive sports literature collections or comprehensive collections of quotations.-L.S.S.

Sports Encyclopedia North America. Ed. by John D. Windhausen. Gulf Breeze, Fla.: Academic International Pr., 1987-

$\$ 32 /$ volume (ISBN 0-87569-094-7). LC 87-138416.

An ambitious undertaking, the Sports Encyclopedia North America (SENA) aims to provide "the most complete reference guide to American and Canadian sports, present and past, that heretofore has appeared in print" (p.vii). The set is expected to be complete in fifty volumes with supplements and indexes issued as needed. Three volumes will be published each year; however the reviewer has seen only volume 1 .

Primarily concerned with sports in the U.S. and Canada, attention is also given to athletes from other areas who have had an impact on North American sports. Also included are international sporting events that include participation by American 
and Canadian athletes. The introduction "From the Editor" indicates all major sports and teams will be covered as well as intercollegiate athletics, athletes whose playing careers are over, each type of sport, major sports awards, major sports facilities, events and tournaments, terminology, and equipment plus the relationship of sports to other topics (i.e., sports medicine, economics of sports, etc.). Statistics and records are included with the appropriate article. In order to be included a sport must meet the criteria of physical activity, national organization, and competition. The articles are signed (unless done by the editorial staff) and include bibliographies. The Sports Encyclopedia North America reflects the growing popularity of sports in North America and will fill an important gap in the scholarly literature of sports.-L.S.S.

\section{SOCIAL SCIENCE}

Lake, Celinda C., and Pat Callbeck Harper. Public Opinion Polling: A Handbook for Public Interest and Citizen Advocacy Groups. Washington, D.C.: Island Pr., [1987]. 166p. \$19.95 (ISBN 0-93328032-7). LC 87-3157.

The presence and influence of polls and surveys are pervasive in contemporary American life. The authors have conducted numerous polls with public interest groups and have targeted this book to those individuals and organizations involved with public advocacy issues. "This book presents hands-on information on how to plan, administer, and analyze a poll. And because polls can be used against you, this book also helps you to analyze the sampling, interpretation, and question-wording of polls conducted by other org[a]nizations." The ten chapters take the would-be pollster step-by-step through the polling process: "Introduction to Polling," "'Getting Started,"' "Questionnaire Wording and Construction," "Interviewing," "Preparing and Managing Your Interviews," "Sampling," "Processing Data: Methods and Options," "Analysis," "Shortcuts and Pitfalls." Each chapter includes tips for success, alerts to potential problems, and checklists that summarize important points, all highlighted graphically. An annotated bibliography, sample questionnaires, grids, and tabulations, and short glossary and index complete the volume. Recommended for all types of librariesJ.B.

\section{WOMEN}

Brady, Anna. Women in Ireland: An Annotated Bibliography. Bibliographies and Indexes in Women's Studies, no.6. New York: Greenwood, 1988, 478p. \$45 (ISBN 0-313-24486-3). LC 87-25043.

So much has been in the newspapers recently about women in Ireland that this new bibliography is a valuable addition. Brady states that her aim is twofold: "to provide quick and convenient access in a single source to what has already been published,. . . to stimulate additional research in the area by indicating what gap exists in the literature. . .and also to facilitate comparative studies designed to differentiate that which is intrinsic in women's biology and temperament from that which is culturally conditioned" (introd). Coverage is stronger for Ireland but women in Northern Ireland are also treated; excluded are general accounts of Great Britain or England if they offer very small sections on Irish women.

All aspects of women's lives and activities are sought, from the Celtic period to the present day. Only secondary sources are listed-books, chapters in books, journal (not newspaper) articles, pamphlets, but not fiction and poetry. The arrangement is topical with each section preceded by scope notes, then alphabetical by authors. Numerous cross-references assist the reader as well as author and subject indexes. The annotations are descriptive rather than evaluative. All in all, a very useful compendium of references for the researcher.-E.M.

Goodfriend, Joyce D. The Published Diaries and Letters of American Women: An Annotated Bibliography. Boston: G.K. Hall, 1987. 230p. $\$ 30$ (ISBN 0-8161-8778-9). LC 87-17908.

Citing other important bibliographies of 
published American autobiographies and journals, Goodfriend has limited inclusion to the personal diaries and letters of American women writing in the United States. Stressing the immediate, rather than the retrospective, Goodfriend has excluded memoirs, autobiographies, and any extensive edited documents. The resulting bibliography includes approximately 700 items, listed in chronological order by initial date of composition. The annotations are very well written and are long enough to encourage browsing. The bibliography is followed by author and subject indexes, and the latter contains entries by topic, profession, religious affiliation, marital status, geographical location, nationality, and much more.

Although there is considerable overlap between this and Arksey's American Diaries (Guide BD473), the emphasis on the personal and immediate in The Published Diaries and Letters of American Women, and the fact that American Diaries does not include letters or deal exclusively with women make both bibliographies valuable resources in a reference collection. Libraries not yet possessing American Diaries will wish to purchase it, but for those which already own a copy, this bibliography provides excellent annotations and a focus on women.-S.S.

\section{HISTORY AND AREA STUDIES}

Cook, Chris. Sources in European Political History. London: Macmillan; N.Y.: Facts On File, 1987- . V.1- LC 827365. v.1, The European Left. 237p. \$35 (ISBN 0-333-23996-2).

Similar in presentation to Sources in British Political History (Guide DC287) also compiled by Chris Cook, the series expects to locate and identify unpublished personal papers of major Western European political figures of the nineteenth and twentieth centuries.

Volume 1 describes "over 1000 individuals active in the socialist, labour, radical, and revolutionary movements in Europe ... from the revolution of 1848 through to the end of the Second World War in 1945" (introd.), excluding papers of the Eastern European, British, and Irish left. Volumes 2 and 3 will cover diplomacy and imperial- ism and war and resistance.

Entries are alphabetically arranged giving name, dates, brief biographical statement, and the location of manuscripts, papers, letters, etc. Occasionally a reference is given to published papers or to inventories. There are two brief appendixes describing archives relating to the Paris Commune and to the Norwegian labor movement.

This series will be a valuable resource for locating primary sources especially since many papers have moved around Europe and are not necessarily in the country where the person lived and worked. An index to the whole series will be a welcome enhancement, and one hopes that Cook and his co-compilers will consider a fourth volume indexing organizations, events, etc. - E.M.

Dictionnaire Napoleon. Ed. by Jean Tulard.

Paris: Fayard, [1987]. 1,767p. Fr 950 (ISBN 2-213020353).

Incorporating recent scholarship and earlier, more specialized biographical dictionaries on the Napoleonic era, this work offers biographies of the famous and less famous figures and extensive articles on major topics such as the continental blockade, public finances, and conscription. The articles, contributed by some 200 specialists in France and abroad, are signed and in general accompanied by a bibliography.

The Index Thematique conveniently groups articles under larger subjects; for example, one may find all the names of people who wrote memoirs under "Memoires (auteurs de)." Under "Nourriture," relevent articles from agriculture to Brillat-Savarin are mentioned.

In a concise, one-volume format, the Dictionnaire contains a wealth of information and is more comprehensive than the Historical Dictionary of Napoleonic France, 1799-1815, edited by Owen Connely (Greenwood, 1985). With black-andwhite illustrations and color plates of $\mathrm{Na}$ poleonic iconography.-J.S.

Encyclopedia of Asian History. Ainslie T. Embree, editor in chief. New York: Scribner; London: Collier Macmillan, [1988]. 4v. \$275 (ISBN 0-684-18619-5). LC 87-9891. 
The purpose of this encyclopedia is to make available "the highest level of contemporary scholarship on Asia to a nonspecialist audience" (pref.). Geographically it covers the area from the Suez to the Pacific, including Iran and central Asia. Signed articles of varied length, but generally brief, cover topics in history, defined as "the interaction of the political, social, intellectual and economic movements that produce civilizations in all their rich and bewildering complexity." Well written and informative, they were prepared by an international team of professional historians. Although the emphasis is on political history, the Encyclopedia includes a number of articles in religion, philosophy, and art.

Most articles are accompanied by a bibliography of English-language works on the subject. The Encyclopedia has a synoptic outline, Wade-Giles/Pinyin conversion table, and general index. The synoptic outline is useful for systematic reading of related articles that form a concise survey of a national history. The black-and-white photographs and maps are well chosen and clearly produced-I.S.

Farenholtz, Brigitte and Wolfgang Grenz. Manual para las Relaciones EuropeoLatinoamericanas: Institutiones y Organizaciones Europeas y sus Relaciones con America Latina y el Caribe. Handbook for European-Latin American Relations: European Institutions and Organizations and Their Relations with Latin America and the Caribbean. [Madrid: Instituto de Relaciones Europeo-Latinamericanas, 1987], 772p. $\$ 50$ (ISBN 84-393-9310-8). LC 87-B84568.

The stated purpose of this handbook is to provide "a guide to institutions and organizations in the member countries of the European Communities concerned with Latin America and the Caribbean" (introd). The compilers note the very broad scope of the project, which they hope will document the wide variety of organizations and institutions that form the basis for interaction between the two regions. In this respect the handbook is a unique tool, for it includes not only academic institutions (such as found in Carmelo Mesa-Lago's Latin American Studies in Europe) and individuals (profiled in more detail in Latinoamericanistas en Europa, compiled by Ida L. Suarez), but also governmental, business, technical, religious, media, and other types of organizations with interests in one or more of the Latin American countries.

The handbook was compiled from the results of a detailed questionnaire, completed by around 500 organizations, supplemented by less detailed information about a larger number of groups. The main part of the book is arranged alphabetically (in Spanish) by country within the European community, and within each country by city. All descriptions are in a standardized format, with text in both Spanish and English. The second part consists of eight appendixes (Institutions and Organizations in Austria, Switzerland, and Sweden; European Peridical Publications with Reference to Latin America and the Caribbean; Diplomatic and Consular Missions of the Latin American and Caribbean Countries in Europe; Bilateral Countries in Latin America and the Caribbean; Bilateral Trade Promotion in Latin America and the Caribbean; European Banks' Representations in Latin America and the Caribbean; European Cultural Institutes in Latin America and the (aribbean) and indexes by personal name, region, subject (English and Spanish), institution or organization, and acronym. Although admittedly incomplete, this handbook fills a gap in the literature.-J.B.

The Middle East. Ed. by Michael Adams. New York: Facts On File, 1988. 865p. \$45 (ISBN 0-8160-1268-7). LC 86-29274.

In a time when so many reference books in area studies tend toward the dry, descriptive, and statistical, it is with admiration that one encounters an editor who refuses to "impose. . . any straitjacket of political or stylistic orthodoxy" and who admits that it "would be unrealistic to look for consistency from authors whose backgrounds differ widely and who are discussing events and conditions in a region that has become a byword for dissension and bitter controversy" (pref.). The forty-one contributors have provided an overview of the Middle East that should prove both useful and stimulating to a variety of researchers and students. 
The first 180 pages are devoted to basic information on each country, followed by thirty-four pages of comparative statistics, most as current as 1985-1986, compiled by the Middle East Economic Digest. The remainder of the volume is divided into five parts: "General Background,'" "The Countries of the Middle East," "Political Affairs," "Economic Affairs," and "Social Affairs." The country sections are expanded versions of the preliminary sketches, while the essays in the last three parts range from "Zionism and the Arab Question" to "Foreign Aid and Investment" and "Archaeology." Each essay concludes with a short bibliography, including both standard and current works. A fifteen-page index concludes the volume. Altogether a work of great utility and scope. $-J . B$.

\section{UNITED STATES}

Allen, James Paul, and Eugene James Turner. We the People: An Atlas of America's Ethnic Diversity. New York: Macmillan, 1988. 315p. \$85 (ISBN 0-02-9014204). LC 87-28194.

Typically an atlas is judged on the quality of its maps, and if maps were all this book had to offer, it would still rank as a first-rate reference tool. There are over 100 maps of the U.S. here, most of them the same full-page outline of state and county boundaries, but each devoted to a different ethic group and shaded, county by county, to represent the percentage, or the absolute number, or both of that group in the population. Using data from the 1980 Census of Population, the authors have made it possible to see in a glance the distributions and densities of nearly seventy different ethnic groups. And by juxtaposing with these maps smaller, state-level companion maps based on datawhenever similar data were availablefrom the 1920 census, they suggest the shifts, trends, and movements of these populations. In addition, there are several maps devoted to particular ethnic groups' U.S. migration patterns. Finally, a number of cartograms-graphs made of nested and proportionally sized rectangles and squares-show the relative proportions of selected ethnic groups in each state.

The authors also appreciate the true purpose of all this elegantly arranged graphic information: "like most maps, these may be best used as heuristic devices to stimulate curiosity" (pref.); one wants to know on seeing these maps how a certain people came to be in a particular place, and why they stayed or left. The text surrounding each map addresses just these questions, not, obviously, to exhaustion-each ethnic group averages about a page of concise prose-but historical factors and trends are broadly identified and traced.

The whole package-maps and text-is so attractive and accessible that some scholars might even find it off-putting; but although a high school student could indeed make good use of this book, its seriousness and scholarship will be appreciated by researchers in history, sociology, and geography.

The text includes a chapter on the quality of data from the 1980 census and a brief but very useful list of references.-W.M.

Gordon, Lois, and Alan Gordon. American Chronicle: Six Decades in American Life, 1920-1980. New York: Atheneum, 1987. 565p. \$39.95 (ISBN 0-689-11899-6); paper, \$16.95 (ISBN 0-689-11901-1). LC 8620621.

A year-by-year look at the last six decades in America. Each decade is introduced by a brief narrative of the social, political, and cultural trends for that ten-year span as well as a brief look at vital, economic, social, and consumer statistics. Categories covered for each year include: Facts and Figures, In the News, Deaths, Quotes, Ads, Radio (later TV), the Arts (Music, Theater, etc.), Science and Technology, Sports, Fashion. A Kaleidescope section attempts to capture the "flavor" of each year by giving costs, popular brands, new words, first appearances, etc. A fun book to browse but a name/subject index would have enhanced its usefulness for libraries.-L.S.S. 
Heard, J. Norman. Handbook of the American Frontier: Four Centuries of IndianWhite Relationships. Metuchen, N.J.: Scarecrow, 1987- . \$40 (ISBN 0-81081931-7). LCCN 86-20326. V.1, The Southeastern Woodlands.

The first of a projected five-volume set, the Handbook of the American Frontier provides brief encyclopedia-like articles in a dictionary arrangement on all aspects of the Indian-white relationship. Subjects covered include "American Indian tribes and leaders, explorers, traders, frontier settlers, soldiers, missionaries, mountain men, captives, battles, massacres, forts, treaties" (p. vii) in the continental U.S. from the earliest explorations to the end of the Indian wars. Each volume will cover a different region: Southeastern Woodlands; Northeast; The Plains; Southwest and Pacific Coast; volume 5 will include the index, chronology, and bibliography. Crossreferences to related articles within a volume are given, and brief bibliographies are provided. Some articles may be split between volumes as tribes moved from one region to another so there may be some difficulty in finding the primary article for some topics until the cumulated index volume becomes available. Although this set has a similar subtitle to the volumes by Francis Paul Prucha, Prucha's Indian-White Relations in the U.S. and A Bibliographic Guide to the History of IndianWhite Relations in the United States remain the volumes of choice for bibliographic citations. Complements the Handbook of North American Indians but is not a substitute for it.-L.S.S.

Prucha, Francis Paul. Handbook for Research In American History: A Guide to Bibliographies and Other Reference Works. Lincoln: Univ. of Nebraska Pr., 1987. 289p. $\$ 21.95$ (ISBN 0-8032-3682-4). LC 8630871.

Francis Prucha, the author of many excellent reference works on native Americans, writes "the purpose of this handbook is to introduce beginning historians to the help that awaits them in the reference sections of the library" (introd.). However, many non-historians-and librarians-may find this Handbook useful as well.

The Handbook consists of two parts. In part 1 are chapters on various types and formats of reference tools, including library catalogs, book review indexes, periodical indexes and abstracts, dissertation lists, atlases, manuscripts, and biographical sources. Each chapter contains essays on the nature and uses of special reference works; many individual entries include brief annotations. Particularly clear and helpful are the chapters on government documents and the federal archives. A short chapter introduces online databases and other electronic information sources. In part 2 are chapters on specific topics in American history such as foreign affairs, blacks, women, regional history, and religion. Emphasis is on recent or cumulative works, rather that older classics that could be located in the Harvard Guide to American History [Guide DB25] or the American Historical Association's Guide to Historical Literature [Guide DA1]. A complete index follows.

Handbook for Research in American History should answer the needs of beginning researchers well. It fills rather neatly the niche between general guides to historical research methods and more specialized subject bibliographies and, if only for North America, replaces the dated Historian's Handbook (Guide DA2).-B.J.

\section{NEW EDITIONS, SUPPLEMENTS, ETC.}

Random House under the editorship of Stuart Berg Flexner has published a thoroughly revised Random House Dictionary of the English Language in a second revised edition (New York: Random, 1987. 2,500p. \$79.95; 1st edition 1966, Guide AD9). Grown to about 315,000 entries, much updated, still descriptive, with an addition of the approximate date for the entry into the language of a word or phrase, it is a most desirable purchase of a contemporary dictionary for libraries and the home.

Clarence Barnhart issues a quarterly newsletter called The Barnhart Dictionary 
Companion January 1982- ; (Guide AD69) in order to "report upon the wealth of change in the English vocabulary" (pref.). Now he has issued an Index to the newsletter for the years 1982-85 (Cold Spring, N.Y.: Lexik House, 1987. 102p. \$36) with 3,200 entries.

British English A to Zed by Norman W. Schur (New York: Facts On File, 1987. 477 p. \$35) is a revision of the author's English English (1980, Guide AD64). The new edition adds almost 10 percent more entries and a new section "Connotative Place Names" to the appendix.

These pictorial or visual dictionaries have become prevalent. First we had the Oxford Dudens (Guide AD311, AD379); now we have Facts On File English/French Visual Dictionary: Look Up the Word from the Picture, Find the Picture from the Word (New York: Facts On File, 1987. 924p. \$32.50) compiled by Jean-Claude Corbeil and Ariane Archambault. The illustrations are much clearer than the Duden and the orientation is more North American since the editors are in Quebec.

Within the Biblioteca Bibliographica Aureliana (Baden-Baden: V. Koerner) issues have been published since 1978 entitled Répertoire bibliographique des livres imprimés en France au XVIIle siècle (nr. 75, 81, 84, 86, $89,91,92,94,97,98,101-103,111$ ) listing by city, chronologically, works published there in the seventeenth century. Now they are beginning a new title to continue the coverage, Répertoire bibliographique des livres imprimés en France XVIIIe siècle (Biblioteca bibliographica Aureliana, 112, 1988). Complementary to the latter Répertoire is La Siècle des lumieres: bibliographie chronologique by Pierre Conlon (Genève: Librairie Droz; Guide AA751). The next two volumes have appeared: v.4, 1737-42 (1986, 525p.), v.5, 1743-47 (1987. 539p. Fr 383) in the series Histoire des indées et critiques littéraire, nr. 239, 250.

Three interesting developments in the field of Latin American bibliography were issued in 1987: a fourth supplement to Arthur Gropp's Bibliography of Latin American Bibliographies (Guide AA77-AA79), this one compiled by Lionel V. Lorona (Metuchen, N.J.: Scarecrow, 1987. 223p., \$25). Besides adding bibliographies in the hu- manities and social sciences published 1980-84, it adds bibliographies omitted from previous supplements. Guía a las reseñas de libros de y sobre Hispanoamérica (Guide AA518) has resumed publication with 1983 in two volumes (New York: Garland, 1987. \$175) still compiled by Antonio Matos. The last fascicule of the Indice alfabetico de titulos-meterias, correctiones, connexiones y adiciones del Manual del librero hispano-americano de Antonio Palau y Dulcet, compiled by Agustin Palau Claveras (Guide AA1083-AA1084) completes the alphabet and adds a short appendix (V. 7: Empuries: Palacite Palau Dulcet, 1987. 425p.).

The second edition of Hans Bartke's Who's Who in the People's Republic of China (Munich: Saur, 1987. 786p. \$175.; 1st ed. 1981 , Guide AJ162) retains about 900 of the original biographies and adds about 2,500 entries. It is again sponsored by the Institute of Asian Affairs, Hamburg.

The obituaries from Variety (1905-86 obituary columns, news stories, and editorials covering deaths of individuals connected with show business) have been reprinted in Variety Obituaries (N.Y.: Garland, 1988. 10v. \$1,250). The arrangement is chronological according to the date of publication; volume 11 is to be an index but is not yet published. Until then Jeb H. Perry's Variety Obits: an Index to Obituaries in Variety 1905-1978 (Guide BG21) can be used as a partial index, although the Perry is very selective.

Benet's Reader's Encyclopedia (Guide BD50) has been revised after more than ten years of work by a staff at Harper's. The third edition (New York: Harper, 1987. 1,091p. \$35) has dropped a great number of short entries, about half nonWestern, mostly identifications of characters or people (Aino Kallas, Kalyb, Kami, Edmund Kean). Added or expanded are current topics or people, and articles with emphasis on "the book's international scope" (pref.). (Kafka expanded, Emmanuel Kazakevich, Elia Kazan and Buster Keaton new.) Otherwise the entries are the same, though the illustrations are dropped.

Long a standard literary dictionary, M. H. Abrams' A Glossary of Literary Terms 
(New York: Holt, 1988. 260p. \$11) is now in a fifth edition. Besides rewriting and updating the entries, the author adds a section on "Modern Theories of Literature and Criticism," which discusses seventeen literary theories. Also very useful is the index with pronunciations given for words likely to be troublesome.

Allen J. Hubin has compiled a supplement to his Crime Fiction 1749-1980 (Guide BD261) covering 1981-85 (New York: Garland, 1988. 260p. \$32). Not only does it include some 6,900 new titles but the volume also adds information about many items in the original work. A new feature is a listing of films based on printed crime fiction.

Fifty Southern Writers before 1900: a Biobibliographical Sourcebook, edited by Robert Bain and Joseph M. Flora (New York, Westport: Greenwood, 1987. 601p. \$75) begins with Captain John Smith and ends with Charles W. Chestnutt. It is a companion volume to Fifty Southern Writers after 1900 described in "Selected Reference Books of 1986-87' in College \& Research Libraries January 1988:66.

Volume 1 of T. H. Howard Hill's Index of British Literary Bibliographies (Guide BD494), which is entitled, Bibliography of British Literary Bibliographies, is now published in a "second edition revised and enlarged" (Oxford: Clarendon, 1987. 886p. \$79). It incorporates the original listings with the additions that appeared in volume 2, pages 183-322, plus other books, parts of books and articles published 1890-1969 that had been omitted from the original bibliography. The index published as volume 6 (1980) of the Index was designed for use with this second edition. Volume 7 is in press and will cover 1970-79 publications.

Harold Bloom and his people at Chelsea House have been very busy this past year. Twentieth-Century British Literature (New York: Chelsea House) is now complete with volume 5, S-Z (1987) and volume 6, Bibliographical Supplement and Index (1987. $\$ 40)$. The Bibliographical Supplement covers 249 authors, listing each one's books with year of first publication up to 1985 and a few from 1986. The New Moulton's Library of Literary Criticism, which began in 1985, has extended its coverage from the Restoration through the Romantic periods (New York: Chelsea House, 1987. V.4-6, $\$ 65$ each).

Scribner has issued supplement one to British Writers, edited by Ian Scott-Kilvert (New York: Scribner, 1987. 465p. \$75; Guide BD573) with twenty-five essays ranging from Graham Greene to Tom Stoppard, arranged chronologically by birth date.

The enlarged and updated edition of Jean-Pierre de Beaumarchais' Dictionnaire des littératures de langue française (Paris: Bordas, $1987.4 v$. \$295) contains 237 pages more than the three-volume, 1984 edition (Guide BD997). More recent publications have been added to bibliographies; some articles wre revised to incorporate new developments on the subject. Among the appendixes are the lists of the members of the Académie Francaise, Académie Goncourt, and winners of various literary prizes, a handy table of literary terms and the title index of all works mentioned in the Dictionnaire. The color and monochrome plates, which are not illustrations for any particular articles but entries by themselves, now have an index.-J.S.

The IBT: International Bibliography of Theatre 1984 (N.Y.: Theatre Research Data Center at Brooklyn College, 1987. \$95) addresses itself to theater books, essays, dissertations, journal articles published in 1984 or omitted from the 1982 and 1983 volumes. The center announced that a double volume covering 1985 and 1986 publications will be forthcoming in fall 1988.

Writers and Production Artists is volume 4 of The International Dictionary of Films and Film-Makers (Chicago: St. James Pr., 1987. 484p., \$55) and includes "a cross-section of writers, producers, art directors, cinematographers, costume designers, composers (and musical directors, arrangers, and lyricists), editors, choreographers, stuntment, and second unit directors, special effects and sound technicians, makeup artists and animators" (introd.). The introduction indicates that this is the last volume of the series but there is mention of a volume 5: Title Index.

The Index to the Motion Picture Guide by 
Jay Robert Nash (Chicago: Cinebooks, 1987. 2 v. $\$ 150$ ) gives complete filmographies for 18,000 individuals active in film 1910-84, as well as an awards index; also included is a series index for titles of movies which form a series, e.g., Blondie or Roy Rogers, and an alternative title index for films released in Great Britain under titles other than ones used in the U.S.

Gale Research has expanded its Encyclopedia of Associations (Guide CA125) to include Regional, State and Local Organizations in seven volumes (Detroit: Gale, 1988- .\$85 each volume). Thus far The Great Lake States and The Northeastern States have been published. Within each volume listings are arranged geographically with keyword and subject indexes. Besides "United States nonprofit membership organizations with interstate, state, intrastate, city or local scope" (subtitle), the volumes include resource and referral centers, clearinghouses, information services, etc.," if they disseminate information to the general public as well as the researcher"' (pref.).

Ralph Chandler, Richard Enslen, and Peter G. Renstrom continue The Constitutional Law Dictionary (Guide CK401) with a supplement one to volume one covering $1983 / 84-1985 / 86$ terms of the Supreme Court (Santa Barbara: ABC-Clio, 1987. 138p. \$26) and volume two, "Governmental Powers" (Santa Barbara: ABCClio, 1987. 715p. \$48.50). This second volume treats "concepts of constitutionalism, biographical sketches of leading justices of the U.S. Supreme Court, and words and phrases common to American constitutional law and landmark case decisions by the Supreme Court" (note).

The International Relations Dictionary by Jack Plano and Roy Olton (Guide CK337) now in a fourth edition (Santa Barbara: ABC-Clio, 1988. 446p. \$42.95) updates terms and concepts and adds a "Guide to Major Concepts" as a modified index.

Volume 2 of The Autobiography of the Working Class: An Annotated Critical Bibliography, edited by John Burnett, David Vincent, and David Mayall (Brighton, Sussex: Harvester Pr.; New York: New York Univ. Pr., 1987. 435p. \$125; V. 1, 1984. Guide
$\mathrm{CH648)}$ covers the years $1900-45$. The Historical Directory of Trade Unions compiled by Arthur I. Marsh and Victoria Ryan (Guide $\mathrm{CH} 702$ ) in its third volume (Westmead, Hants.: Gower, 1987. 525p. \$83.50) covers the building and allied trades; transport, woodworkers and allied trades; leather workers, enginemen, and tobacco workers.

Allen Smith has compiled a Directory of Oral History Collections (Phoenix: Oryx Pr., 1988. 141p. $\$ 74.50$ ) based on answers to questionnaires sent to members of the Oral History Association and to institutions listed in library and oral history directories. The arrangement is geographical with subject and interviewee indexes. Smith lists more libraries and archives (though only in the United States) while Alan Meckler's Oral History Collections (N.Y., 1975, Guide DB63) has more extensive indexing, descriptions of individual histories, and a few foreign collections.

The 1987 edition of International Guide to African Studies Research (London: Saur, 1987. 264p. \$72) is the first since 1975 (Guide DD59). Published under the auspices of the International African Institute, and compiled by Philip Baker, the new edition is considerably expanded, to 1100 entries-J.B..

People in History: An Index to U.S. and Canadian Bibliographies in History Journals and Dissertations (Santa Barbara: ABC-Clio, 1988. $2 \mathrm{v} . \$ 137.50)$ is the latest production from the America: History and Life (Guide DB47) database, 1976 to the present. Alphabetically arranged by biographee with a subject index and author index, the volume indexes all articles (including Dissertation Abstracts International, Guide AH19) "in which the focus was primarily biographical" (introd.). The company indicates they plan to issue a volume based on Historical Abstracts and to provide supplements to both.

James A Ruffner and Frank E. Bair have issued The Weather Almanac in a fifth edition (Detroit: Gale, 1987. 811p. \$110; 4th ed. 1984. Guide EE159) to update material, if possible, to 1985 . A special feature is the section on the problem of upperatmosphere ozone. 